\title{
THE ASSESSMENT OF EFFECTS OF LOCAL GOVERNMENT ELECTIONS IN POLANDIN 2018
}

\author{
Piotr ZientARSKI ${ }^{1}$
}

Alcide De Gasperi University of Euroregional Economy in Józefów (Poland)

\begin{abstract}
The territorial government election held in 2018 had significant influence not only on the current situation in Poland but also on the functioning of the country on the international scene. This event was very important for building the future political situation in Poland and it was a kind of prediction before the European Parliament election, the Polish Parliament election and before the Presidential election which are coming in the following years. The results of this election showed not only what can happen but also how Poland may function in the international environment - the Polish cooperation with other countries in the region and Poland's functioning in the European Union. The subject of this research is to analyse the territorial government election in Poland in 2018 and to show what kind of changes were done in the Polish electoral law. Also, there are some indications presented how the role of local government should be shaped in the near future. The paper is also discussing some issues related with the way how Poland will function in the future with the focus on international cooperation, especially the cooperation with neighbouring countries and the European Union. The method which was used in this study is the observation method and the analysis of the situation in Poland as well as the analysis of changes in the electoral law in Poland. The aim of this paper is to show what changes should take place in the near future in the role and shape of territorial governments in Poland on different levels seeking to improve the functioning of these very important bodies of the political system in Poland.
\end{abstract}

KEYWORDS: elections 2018, commune, local self-government, Senate.

JEL CODES: K 16, Z 18.

DOI:

\section{Introduction}

The territorial self-government in Poland already has its established tradition and experience. The local government election held in 2018 , for several reasons, was particularly important. The subjectivity and independence of the territorial self-government, expressed in the Constitution of the Republic of Poland and concretized in the self-government acts, has a systemic significance for determining its position in the state and in the law. One should agree with the statement that territorial self-government is a key principle of the organization of public administration in Poland. The local government units, i.e., the commune, the districts and the self-governments of voivodships, are entities equipped with rights and obligations and they are entities performing the public tasks. They can be defined as independent, created on the basis of law, corporations of the local society, with their own internal organization, equipped with the legal nature, being a subject to state-related supervision in certain areas. The genesis of this article was the local government elections in Poland carried out in 2018.

The election for territorial government held in 2018 had great influence not only on the current situation in Poland but also on the functioning of the country on the international scene. This event was very important for building the future political situation in Poland and it was a kind of prediction before the European

1 Piotr Zientarski - dr., lawyer (advocate) and politician, senator of the Republic of Poland since 2005. Alcide De Gasperi University of Euroregional Economy in Józefów, Poland

Scientific interests: law science, social and political science, studies about self-government

E-mail: biuro@zientarski.pl 
Parliament election, the Polish Parliament election and before the Presidential election which are coming in the following years. The result of this election showed not only what can happen but also how Poland may function in the international environment - the Polish cooperation with other countries in the region and Poland's functioning in the European Union.

The subject of this research is to analyse the territorial government election in Poland in 2018 and to show what kind of changes were done in the Polish electoral law. Also, there are some indications presented how the role of local government should be shaped in the near future. The paper is also discussing some issue related with the way of functioning by Poland in future with the focus on international cooperation, especially cooperation in neighbouring countries and the European Union.

The method which was used in this study is the analysis of the situation in Poland and the analysis of changes in the electoral law in Poland. Also, the method of observation and description of the phenomena happening in Poland, which are the consequence of changes in the electoral law. Finally, in the study, the forecasting method was used to predict the political and social consequences of the election results on Poland's future assessing an internal and external situation.

The aim of this paper is to show what changes should take place in the near future in the role and shape of territorial governments in Poland on different levels seeking to improve the functioning of these very important bodies of the political system in Poland.

\section{Local government}

A well-known lawyer, professor Michał Kulesza, claimed that: "Today, the activities of public administration - especially territorial self-government - go far beyond the classical sphere of order and regulation imperium, focusing largely on meeting collective social needs and development management, which largely depends on applying non-judgmental actions, using public property - dominium" (Kulesza, 2006).

The model of territorial self-government in Poland, in the country undergoing the reconstruction of state mechanisms, is a reflection of the solutions of its creators, i. e. prof. Michał Kulesza, prof. Jerzy Regulski, the former president of the Constitutional Tribunal Jerzy Stępien and the local tradition and culture, as well as the economic, political and geographical conditions. In Poland, as in other Central and Eastern European countries, was created a system of territorial self-government complying with the standards of the Western European rule of law. There is a well-established view that local self-government is a way of exercising public authority and organizing local administrative activities. In addition, the territorial self-government is certainly a legal institution that allows the implementation of a group public interest. Moreover, it is the value of the Western political culture embedded in the ideas of its civilization, especially in the idea of freedom and social pluralism.

In the political sense, the local government units are a way of empowering the local (in the commune and in the district) and regional (in the voivodships) society. It is worth noting that the territorial self-government and its political position is an expression of the idea of citizens' participation in solving the problems and needs of collective community life. The functions of the local government are democratization, decentralization and subsidizing the state and state power, as well as striving to improve the quality of life of individuals and their communities. Therefore, there is no doubt that territorial self-government is a school of democracy and politics.

The legal bases for the operation of local government administration are regulated by the provisions of the Constitution of the Republic of Poland, and at various levels, and they are described by such acts as:

1. The Act of $8^{\text {th }}$ March 1990 on local self-government [Journal of Laws of 1990, No. 16, item 94] - hereinafter referred to as a.1.sg.

2. The Act of $5^{\text {th }}$ June 1998 on district self-government [Journal of Laws of 1998, No. 91, item 578] - hereinafter referred to as a.d.sg.

3. The Act $5^{\text {th }}$ June 1998 on voivodship self-government [Journal of Laws of 1998, No. 91, item 576] - hereinafter referred to as a.v.sg.

4. The Act $28^{\text {th }}$ July 1998 on the introduction of the essential three-tier territorial division of the state [Journal of Laws of 1998, No. 96, item 603]. 
In the context of the objective assumed in this article, the provisions of the Act of $5^{\text {th }}$ January 2011 - the Election Code (Journal of Laws of 2018, item 754, item 1000 and item 1349) are of particular importance. Specifically, it is about the article 1 of the Election Code which defines the rules and procedure for the submission of candidates and the conducting and conditions of the validity of the following elections for: 1) the Sejm of the Republic of Poland and to the Senate of the Republic of Poland; 2) the President of the Republic of Poland; 3) the European Parliament in the Republic of Poland; 4) the bodies constituting local self-government units; 5) the commune head, the mayors and city presidents.

\section{The importance (meaning) of local government elections}

in 2018 for the national economy

As at no level, in the municipality, there is the mass-scale provision of services to population. In the local government elections, we choose not only local authority, but also - what is equally important - management of a kind of an enterprise that satisfies or organizes the satisfaction of the most important needs of the local community. "Enterprise - commune" not only has the assigned tasks, but sometimes also has significant funds for their implementation. The market of municipal services in Poland is estimated at around 40 million of recipients. Here are the following main markets: the municipal waste market, the local transportation market, the media market supply, the public property management, etc. If after the parliamentary elections or the presidential election, we "stop" the information media (television, the Internet, radio), we will not be able to feel the direct consequences of the change of "power" for a long time. Whereas the change of the commune head, the mayor, the city president or the members of commune board, we will notice in a few weeks, for example by changes in water supply tariffs or positions in municipal enterprises.

Let us explain why in the current legal situation, the local government is not only independent, but also authorized to shape economic relations in a manner best suited to its interests.

According to the article 164, paragraph 1 of the Constitution of the Republic of Poland, the commune is the basic unit of the local self-government. The Constitution recognizes territorial self-government as part of the public authority system, which results primarily from the article 16, paragraph 2 and the article 163 of the Constitution. These provisions establish the principle of the participation of local self-government in the exercise of public authority, and the tasks that are assigned to it must constitute "an essential part of public tasks".

The territorial self-government means a structure which is entitled as independent from other forms of public authority, and in particular in relation to government administration bodies. The essence of self-government is management of public affairs by the interested parties themselves or their representatives. The local government that performs part of its tasks performs on its own behalf and on its own responsibility. The institutional and, above all, the functional autonomy is the constitutional feature of the territorial selfgovernment.

\section{Two related roles}

The commune, as an element of the national legal order, requires a multi-faceted analysis. Let us pay attention to the economic nature of the commune's activity, which as an entrepreneur provides communal services to residents. At the same time, the municipal council as a public authority is creating the acts of local law necessary to regulate the performed tasks. These two roles, though interrelated, cannot be intermingled. The units of territorial self-government, including municipalities (communes), do not have only the features of public authority. They are also the subjects of civil law. The issue of the legal subjectivity of a commune (public or private) is related to the forms of its operation, therefore the analysis of the status of a commune as an element of public administration and a civil law entity, including in particular an entrepreneur, should be separated. This intention, unfortunately, sometimes only remains, which translates into local economic relations.

The legislator has not introduced a common regulation for the local self-government as a collective concept. The only exception is the act on municipal economy regulating municipal activities by the all local 
self-government units. However, the Constitution emphasizes the special role of the municipal (commune) self-government. Pursuant to the provisions of the article 164, paragraphs 1 and 3, the commune is obliged and at the same time entitled (in the article 166) to carry out all tasks aimed at satisfying the needs of the community, and not reserved for other local self-government units. The article 6, paragraph 1 of the Act on municipal self-government, develops a constitutional norm, assigning to the municipality all public matters of local significance, not reserved by statutes for other entities. Without diminishing the functions of a district or a voivodship self-government, it should be noted that their impact on the situation of a resident as a recipient of communal services is limited and, as per rule, indirect.

According to the constitution, the commune as a territorial self-government unit, is obliged to perform the public tasks on its own behalf and on its own responsibility. Another approach to the municipality's tasks is represented by modern management: "local self-government" should be understood primarily as the right and real ability of local communities, within the limits set by law, to manage and run a fundamental part of public affairs under their own responsibility and in the interests of their residents, in accordance with the principle of subsidiarity (Jagoda, 2011). It is worth noting that there is the fundamental difference between the obligation to perform the public tasks, contained in the article 16 of the Constitution, and the right to run and manage the public affairs, as it is referred in the article 3 of the European Local Self-Government Charter. The "management of public affairs" should be understand as the forms of execution of the self-government task. This justifies a departure from the direct implementation of tasks by municipalities, while maintaining their regulatory functions at the same time entrusting the tasks themselves to entrepreneurs.

In order to better understand the role of self-government, reference should be made to the principle of subsidiarity as a general principle of administrative law describing relations between particular levels of government in the state, in particular between local and central authorities. The subsidiarity as a principle has been mentioned in the preamble of the Constitution along with the principle of respect for freedom and justice. It means that the tasks and competences of local government units should be implemented at a sufficiently low level, with the funds necessary to achieve the goal. As a legal norm regulating the functioning of the territorial self-government, the subsidiarity was included in the European Charter of Local Self-government (ECLSG) and in the article 4, paragraph 3 and 4 of this document is defined as follows:

"3. Public responsibilities shall generally be exercised, in preference, by those authorities which are closest to the citizen. Allocation of responsibility to another authority should weigh up the extent and nature of the task and requirements of efficiency and economy.

4 Powers given to local authorities shall normally be full and exclusive. They may not be undermined or limited by another, central or regional, authority except as provided for by the law."

The public tasks should therefore be carried out at the lowest possible level of public authority. If a commune is able to manage them, it is not necessary to involve another level of local self-government. The possibility of concluding agreements by the local government units gives the basis for a practical division of tasks not only between the territorial self-government and local government administration, but also between the commune, the district and the voivodship. The Constitution assigns most of the public tasks to the municipality (commune) and the principle of subsidiarity also indicates that the commune is appropriate for their implementation. On the other hand, the commune has the right to delegate these tasks beyond its structures resulting from special regulations, in particular to entrepreneurs. The relevant regulations here are: public procurement, the public-private partnership or the act on concession contract.

The commune performs not only its own tasks but also the commissioned ones, and here we experience a peculiar marriage of local and central authorities. If they are close to each other, the synergy effect may impress, on the contrary, if they compete with each other, it may be a conflict field. The process of commissioning tasks to the municipality raises the questions about who "disposes" with a specific mandated task, i.e., whether the municipality implements it independently or it operates on behalf of the government administration.

An unambiguous answer is given by the Supreme Court in the judgment of $12^{\text {th }}$ March 2004, II CK 64/03. It states that the use in the article 8 of the a.l.sg. and in the article 8 , paragraph 1 of the act on the division 
of tasks and competences specified in particular acts between the commune authorities and government administration bodies and on the amendment of some of the acts, the commissioned task is, assuming the consistent use by the legislator of terms on the legal connotation, a clear reference to the contractual obligation provisions. The use of this term, and not a synonymous term, devoid of the civil law context, entitles to accept that between a government administration body whose tasks have been delegated to commune to be performed as the commissioned task, and this municipality, arises a relationship with the content corresponding to the contract-order within the meaning of the article 734 and the following of the Civil Code.

This means that in the absence of a different contract the contractor is authorized to perform actions on behalf of the principal (article $734 \S 2$ of the Civil Code). Therefore, it can be reasonably assumed that the contractor is entitled to incur obligations related to the performance of the ordered activities on behalf of and for the benefit of the client. The commissioned tasks are carried out by the municipality on behalf of other public administration bodies, in particular the government administration. The commune as a contractor, however, has limited autonomy in the freedom to choose the form of their implementation. Therefore, in the case of commissioned tasks, the commune represents the commissioner and operates within the scope of its assigned order. This again gives a wider scope for cooperation in the absence of a conflict, but the possible conflict increases the control over the implementation of these tasks.

And so, we come to the heart of the discussed problem. At no level of state management as at the municipal level, there is no such mass-scale services for the population. Consequently, the changes or maintenance of the local status quo will translate into the situation of local or network municipal entrepreneurs who will closely observe the results of the local government elections, supporting the existing government or, on the contrary, looking for their opportunity for changes. This in turn will translate directly into the wallet of us all more than nationwide programs.

\section{Self-government at the beginning of the 21 st century}

By implementing the action called "The self-government of the 21 st century", one of the Polish newspapers - "Rzeczpospolita" - opened the debate on the future of Polish self-governments. The campaign, and immediately after its completion the local elections was a good time to start a substantive discussion about the Polish self-government and its position in the modern state. Introduction of the territorial self-government is one of the fundamental reforms after 1989. It was the milestone in the process of shaping democratic Poland, building small homelands and developing civic awareness.

The civilizational and technological leaps, as well as the changing social reality imposes that before starting such a discussion the Polish self-government should be reviewed. It must be assessed whether its development went hand in hand with the pace of political, economic and social changes. The problem of relations between local and central authorities and the issue of financing the commissioned tasks at the central level has been unresolved for years. The discussion about the future of districts is still unfinished. Do they need to be reformed, or maybe the liquidation of this level of self-government is necessary? Does the influence of local governments on decisions taken in Warsaw should be strengthened? Should the idea of the new role of the Senate as a chamber of local government be reappointed?

The imperfection of the electoral law in turn is revealed in the local government campaign showing how easy political parties break them in the light of the flash during the so-called pre-campaign. There are many urgent economic issues waiting for the discussion, such as the optimal use of structural funds. Over $70 \%$ of Polish investments are local government projects which determine the level and quality of life of residents. Hence, the questions about the role of strategic planning in local government units, about the cooperation of local government authorities with local business, about the opportunities for sustainable development of regions, should be asked. The demographic problems of cities is a separate issue which needs to be solved.

There are many such questions. Therefore, it is useful to notice the activity of the "Rzeczpospolita" editorial office, opening a nationwide debate on its pages and on the rp.pl portal in a special website service available at www.rp.pl/samorzad 2018. 


\section{The local elections 2018 were a difficult exam before electoral commissions}

The local elections in 2018 were a special challenge to ensure the objectivity, transparency and efficiency of electoral bodies. In the current Constitution of the Republic of Poland, the active electoral law is included in its chapter II as a human and citizen's law. In the accordance with article 62 of the Constitution, a Polish citizen has the right to participate in the referendum and the right to elect the President of the Republic, the deputies, the senators and the representatives to local self-government bodies if he or she reaches 18 years of age at the latest on the day of the voting (a day of election). The right to participate in the referendum and the right to take part in the election is not granted to a person who, based on the final court decision, is legally incapacitated or who is deprived of public or electoral rights.

It is worth reminding that already in the Universal Declaration of Human Rights of $10^{\text {th }}$ December 1948 , in the article 21 was specified that:

"1. Everyone has the right to take part in the government of his country, directly or through freely chosen representatives.

2. Everyone has the right of equal access to public service in his country.

3. The will of the people shall be the basis of the authority of government; this will shall be expressed in periodic and genuine elections which shall be by universal and equal suffrage and shall be held by secret vote or by equivalent free voting procedures"

On the other hand, The Additional Protocol No. 3 to the European Convention for the Protection of Human Rights and Fundamental Freedoms states that "the High Contracting Parties undertake to organize at reasonable intervals free elections based on secret ballot, in the conditions ensuring freedom of expression of the public opinion in the choice of the legislative body".

During the Communist system in Poland, the parliamentary elections were only a ritual plebiscite act, devoid of any real legal and political significance. Only the parliamentary elections of $4^{\text {th }}$ June 1989 , not yet fully free and called contractual ones, were of fundamental importance for the commencement of the transformation process in Poland, and the electoral law for the Sejm of 1991 formed the State Electoral Commission in a form valid until today - as a permanent body, consisting of nine judges appointed by the president.

Analysing the elections for local government units in 2018, it is impossible not to refer to the elections in 2014. Unfortunately, they have been negatively recorded in the history of the Polish elections. They were accused of having been falsified on a mass scale, which of course is the unauthorized point of view. They were undoubtedly honest. Events such as a failure of the IT system, significantly delaying the date of announcement of the election results, the criticized solution in the form of a voting card as a booklet, the exceptionally high election result of the PSL party, different from the one anticipated in the polls, as well as a significant number of invalid votes, especially to the voivodships self-government, caused the massive criticism of the National Electoral Commission, which resigned as a result of these events.

The unfounded accusations of the election fraud were confirmed by a team of lawyers, sociologists and political scientists, appointed by the Foundation of Stefan Batory, who examined and recalculated votes in randomly selected voting districts, stating that there were no grounds to put forward a thesis about the election falsifications. About $70 \%$ of examined invalid voices were not valid due to the lack of selection of the preferred candidate (empty votes, mainly for the voivodships self-government). The remaining invalid votes were given to more than one candidate (so-called multi-crossed votes). In turn, the good result of the PSL party was contributed by placing this party on the first page of the brochure (a voting card).

In January 2018, the changes were made to the electoral code. The most important ones included: the departure from the judge's system in the commissariat structure, and in the future in the NEC itself, the change of the appointment of commissioners and the head of the National Electoral Office, the appointment of electoral officers' bodies, the introduction of cameras in polling stations (however, the legislator ultimately resigned from this requirement), the extension of the privileges of trustees, a new way of voting on the electoral card or the introduction of two types of voting committees, i.e. one to conduct a vote and the second to determine the results of the vote. 
Contrary to some opinions, these changes did not significantly increase the transparency of elections, as this transparency and the transparency of the electoral procedure was sufficiently assured by the existing provisions. This was demonstrated by, for example, the parliamentary elections held in 2015 and presidential elections. From almost 2 thousand election protests, which were examined by the Supreme Court, only in approximately 50 cases, the Court saw an infringement of the electoral law, which obviously had no effect on the general election result.

The guarantees for reliable counting of votes and determination of election results are very elaborate in the electoral law. The electoral representatives have the right to report to the members of electoral commissions (although their statutorily defined composition gives an unjustified advantage to committees appointed by parties and their coalitions), men of trust to the majority of electoral commissions. The power of the trustees in relation to the observation of the voting process, the counting of votes and the transfer of election reports to the higher-level commissions (including the NEC) has been significantly increased. Representatives of international and national organizations have the right to participate in the election, for which statutory objectives include the care for democracy, civic rights and development of civil society.

The provisions of the Electoral Code also provide possibility to appeal from the decisions of electoral authorities made in connection with elections to the National Electoral Commission, and then to the Supreme Administrative Court.

An important element of the election procedure is the legitimacy and manner of the division of the commune into electoral districts, carried out so far by the commune councils, and from $1^{\text {st }}$ January 2019 by electoral commissioners. This division undoubtedly affects the mechanism of action of the election formula due to the possible mechanical, but also - which cannot be excluded - deliberate deformation of election results. An example of such a phenomenon may be gerrymandering (Wałdoch, 2016), i.e., deliberately shaping electoral districts in such a way as to give electoral benefits to one of the groups taking part in the election.

The National Electoral Commission, in the deadlines provided for in the Electoral Code, considered many appeals against the provisions of electoral commissioners deciding the complaints lodged by voters on the findings of communes regarding the division into counties. These challenged provisions do not seem to be motivated by political considerations - they were rather due to the lack of experience of some commissioners appointed to carry out the upcoming elections for the first time and undertaking their duties in a time relatively close to the elections to local government units, which are the most difficult to carry out all the choices provided for by the electoral code (Zychal, 2017).

The January amendment introduced to the electoral code the institution of the Corps of Election Officials appointed by the head of the National Electoral Office. In local governments, a conviction was born that they strongly limited their role in the organization of elections and delegated some of their duties to the members of the newly appointed corps of officials.

The National Electoral Commission referred to this position, explaining that the provisions of the Electoral Code governing the above issues, as a result of the above-mentioned amendment, were only slightly modified. The Code still assumes a significant role of local self-government among election organizers, because according to the regulations, the commune head, the district head and the marshal of the voivodships are obliged to provide service and technical-material working conditions of district and territorial electoral commissions and what is particularly important and worth emphasizing - the performance of related tasks with the organization and conduct of elections respectively in the area of the commune, district and voivodships.

The local self-government bodies should therefore carry out, as usual, the electoral tasks in cooperation with electoral officials, as it was called for by the State Electoral Commission, appreciating the current role and involvement of local self-government in the organization of the elections.

The Prime Minister's decision on setting the date of the local government election has launched a calendar of particular electoral activities carried out by the municipalities, the electoral commissioners, the electoral officials, the National Electoral Office and the National Electoral Commission. They were run smoothly and in accordance with the set deadlines.

The elections for the local government authorities held in 2018 were undoubtedly a difficult exam to check the objectivity of electoral bodies, their efficiency in the operation and transparency of the electoral procedure. 


\section{The cost of a new electoral law}

The preparation of the local elections and the situation after the amendment of the electoral code has started a large dispute over the assessment of the regulation's effects in terms of the burden on the state budget.

The new regulations introduced additional costs. A total of 605 million 154 thousand 403 PLN, according to public information provided by the National Election Commission and the National Electoral Commission. In addition, there was an increase in the cost of electoral commissioners' salary, the amount of which went up. In addition, there could be the extra cost for the transmission from 28 thousand district commissions calculated at 84 million zlotys, counting 3 thousand PLN per one commission. If you actually buy these cameras, this amount is not enough. There are costs of paying to electoral officers: PLN 4473.55 for each of them, they will work a maximum of three months from the election order. All together it is 32 million PLN for working conditions for these electoral officers plus 8 million PLN for equipment costs and the highest amount of 112.5 million PLN for payments for people working in district commissions (Gruszeczka, 2018).

\section{The state's administration: difficult and uncomfortable tasks} passed to the levels of self-government

After the president's successfully failed initiative regarding the referendum, or in other words the scope of changes in the constitution, a few barely mentioned topics remained. Some circles took this initiative seriously and joined the discussion about the presence in the future constitution of the planes in which they operate.

An important topic was a few voices regarding the systemic positioning of the territorial self-government in a new system order. Unfortunately, these threads were limited only to a few detailed ideas of changes that would not disturb the essence of the state government and local government relationship. It seems that now both these planes run side by side, while the state has a relation to self-government, at most indifferent, more often hostile. It is simply a state that is being upholstered that hates competition. In order to get out of this spiral of self-government pulling down, and as a result the whole public sphere, we should not think about changes in the current state, but about the actual self-governance of the political system, or fitting it into the most important process, which self-government often falls victim to law making at the national level.

It seems necessary to return to the rules of checks over balances, i.e., creating mechanisms of balance of the most important institutions of the state, which, by acting on each other would maintain the state system in a dynamic balance. These mechanisms, immersed in the today's version of the constitution, seem to have only declarative significance over time. That is, they are in the constitution, but their mutual interaction causes them not to create balance.

Even the outside observer will notice that after receiving the same power for the second time (re-election) by the same team, all the mechanisms that force them to look at other institutions or former rulers from competing teams do not work. The Polish system is stable only with complete monopolisation of power because if we have, for example, president from one political side and the parliament majority from the other political side, then we have a conflict that could destabilize the functioning of the state. If we have unity in both bodies, we have uncontrolled control in the hands of one option (Robertson, 2009).

The Polish system is stable not when different vectors disappear, but when all are the same. It is a denial of pluralism. Our democracy works only in the monopoly version, which excludes the essence of democracy or compromise. To this should be added the issue of the electoral calendar and the accumulation of the majority of electoral decisions at one time. This gives the winners the comfort of free operational governance, but also the privilege of shaping the law without looking at the opposition, or even their own voters. The winner takes everything, but it always takes place in the realities of "the earthquake" - then we have the personal and the conceptual exchanges in state-owned companies and administration. We lose the most important value of the modern state - continuation of strategic thinking about Poland.

Let us remind that in the Montesquieu's tripartite power, the parliament should have the element controlling its potential populism - it was a senate, made up of people with a high census. They were supposed to be 
citizens who proved their ability to break above particularism. The structure of the Senate in the Constitution of the Third Republic of Poland does not meet such conditions. It is only a repetition of elections to the Sejm, so the party winner in the Sejm always takes the Senate, which means that the Senate would control itself, or rather its own political base. This is not the case at present: the Senate is called a chamber of reflection, which in fact means that the upper house "eliminates" the parliamentary errors. The Senate either only accepts the Sejm laws, or improves them at the request of its political centre, which causes only inflation of the bad law, because somehow the poor legislative process based on previously unknown haste allows flagrant legislative errors.

According to the idea of checks over balances, it seems that the role of the Senate should be a no-party, pragmatic and, in a sense, no-ideologized revision and control of the activities of the Sejm. The Sejm, which in the fever of political struggle may release (and repeatedly do) legal bribes which harm Poland and Poles. Currently, the only factor that could overcome such situations could be the Senate composed of local government officials, with particular emphasis on territorial self-government. The quickest way to balance the harmful state's insistence is to transform the Senate into a self-government chamber

Does the local government now have the competence to perform such functions? I am convinced that yes, and for several reasons. First, the local government, especially the territorial one, is the sphere of public activity that shapes the quality of our lives to a greater extent than the state. This is where the main source of investment, planning and development of the present Poland beats. This process is further strengthened by the regional financial perspective of the European Union. The competences of local government officials in the public sphere are therefore confirmed.

Secondly, the local government, especially the territorial one, lives in Poland under the constant pressure of the state regulation, having no influence on it, and bearing all their consequences. The principle of subsidiarity or the transfer to the lowest level of competencies that can be realized there, has been reinterpreted in Poland in a truly dialectical way. Inconvenient and arduous tasks the state willingly gives to local governments, "saving" on the occasion of the money for their implementation. In this way, in the case of a shortage often caused by underfunding activities, the state can always blame others. The local government knows these tricks. local government regulations would have to go through "their" chamber, which would make the actions and decisions real.

Finally, the local government officials are able to quickly assess the costs and effects of legal acts and government decisions. Studying the Journal of Law and the confrontation of law with life is their daily bread. Such competences of the members of this body would be useful for the Senate as they are not present at the moment. They would complement the activities of the Sejm and the government, which neglect the process of assessing the impact of their regulations. It is difficult to control when you have full power.

The existence of a local government chamber would have a multidimensional positive impact. It would allow to merge the self-government in a homogeneous structure. It would give a voice that gives meaning and understanding to the activities and the rank of self-government, the voice which is currently inaudible. Thanks to the chamber, the self-government itself, which is essentially nonpartisan, would ultimately be refrained, would end up waiting for parts in the hallways to listen to something in Warsaw. In the today's political situation, the existence of the Senate in the form of a local government chamber would cement the political scene, whose current state leads to a Polish-Polish war weakening the state. It would also be a permanent heritage left in the sphere of the political system. Other, less "systemic" forms could end up in revocable or negligible forms of public consultation, that is, in the forms currently practiced.

\section{Time for compromises}

However, there is an important objection - the elections to the Senate should take place two years before or two years after the elections to the Sejm. In this way, we would avoid the danger of the power jump, i.e., a sudden one-time exchange of key institutions by one political option. It would also give the ruling power a space for self-control reflection and to look at the effects of their actions earlier than once every four years, just before the fever of new elections. 
And another objection: an additional replacement of the Senate system is needed. The repeal of the Senate's amendments or act by the Sejm would require not, as currently, an absolute majority, but a qualified majority, that is $2 / 3$ of votes. Without this change, the Senate would once again be only a chamber of "reflection", because every initiative of the Senate could be repealed by the parliamentary party majority, which always appears. With such criteria, it would force a tribal parliament, divided into two camps, to compromise over the divisions, the first in the history of the Third Polish Republic. The parties would finally learn democracy, and the quality of the law under such control of the Senate would increase.

\section{Self-government election in 2018 as the prediction of the future}

The current political satiation in Poland is complicated and confusing. All opinion polls show that the ruling party has the majority and it should win the future elections. On the other hand, the analysis of the election results to the self-government in 2018 shows that it is possible for opposition parties to obtain the majority if they are able to be united. A scenario is possible where the PIS, as a single party, wins the election, but a united opposition is able to create a parliamentary majority and rule the country.

The remainder of the PIS in power will mark further changes in the Poland's internal situation, as well as changes in the functioning of the country on the international arena.

Maintaining the majority by the PIS, while winning the presidential election by Andrzej Duda or another person from this party, will lead to further radicalization of the Polish political scene. The further changes in the Polish judicial system or changes in the issue of nationalization of the media are possible. The direction of these changes has been very negatively assessed by international organizations, including European Union institutions (Kowalczyk, 2018).

The previous parliamentary elections indicated that a fairly effective way to win the election is to use the social assistance tool - welfare. The politicians willingly formulate election promises, on the basis of which they guarantee the society more and more privileges, including additional material help. If the PIS retains power in Poland, at least some of these promises will be fulfilled and this may have negative consequences for the Polish economy, since the widespread use of the welfare tool is very expensive (Banaszak, 2018: 16-24).

While maintaining the political status quo, the situation of Poland on the international arena will continue to change. It seems possible further conflicts between the Polish government and international institutions, including the European Union. This may translate into the perception of Poland as a stable international partner and the weakening of the country's importance in Europe and in the world. The conflict with the European Union and some of its countries may also lead to a reduction in EU financial support for Poland, in the new budgetary perspective.

In addition, the maintenance of the PIS in power will lead to further tightening of cooperation with such European countries as Hungary or political and social groupings in other European countries which are widely recognized as anti-European bodies. Perhaps, this will not lead to a radical step which would be "polexit", but it can radically change the principles of the European community.

During the local elections in 2018, in many places in Poland, the united opposition overcame the ruling PIS and this party has no power at local government levels. The strategy adopted for the 2018 elections showed that it can be an effective tool for removing the PIS from power, also at the national level. The results of the local government elections show that it is possible for the opposition to seize power, but only in the conditions of cooperation between various groups that are in opposition to the government. These parties must create a common platform, the principle of which will be not only the anti-PIS idea but also a positive program promoting the principles of solidarity and a pro-European approach.

The seizure of power by opposition parties in Poland may lead to maintaining the rule of law and an attempt to rebuild Poland's position in the international arena. It will also lead to conducting the pro-EU policy and cooperation between the European Union institutions and other countries in Europe. 


\section{Conclusions}

During the discussion on the changes in the constitution, many voices were raised about the change of the position of such an important element of public authority in the state as is the territorial self-government. Unfortunately, even the voices of the local self-government leaders lead us to the empty but beautiful declarations of the system's legitimacy. The declarative perspective of postulates is the easiest way because it does not impose any obligations on the authors. On the other hand, the fulfilling of the postulate on transformation of the current Senate into a local government chamber would be a permanent anchor that would permanently fix the local government as an important element of the public authority system, and it would have an impact on the whole country, which is the sum of small homelands. This would give the local government a chance to appear in public space, and by institutionalizing its pragmatism at a higher, systemic level it would begin the elimination of the harmful effects of the Polish-Polish party war from public life.

The self-government election in Poland in 2018 showed that there is a need for some changes of the role and shape of the self-government. Today, the decentralization is a necessary process of management of democratic countries. The changes in the law provisions should lead to making the role of self-government more important. Self-government should have influence on the functioning of the country and participate in the formation of the system of the country.

The election of 2018 also shows that the political situation in Poland may change in the near future. There are two scenarios possible. First of all, the PIS is still in power, after the coming election for Parliament we will observe the radicalization of the political scene in Poland and more unacceptable changes in the law system, such as decrease of the power of economy and the increase of the conflict with many international institutions, including the European Union. The second scenario implies that the united opposition which is getting power may try to make all necessary changes to correct the situation in Poland, keeping the rules of law and democracy and seeking to improve Poland's image on the international scene.

The election of 2018 held at the local level, illustrates that even though the PIS remains in the winning position in Poland, there is a possibility to conduct changes in the country. The strategy used by opposition parties in the self-government election maybe the same as during the Parliament election, in this way, it is possible that the PIS will lose power in Poland. According to many experts, this scenario will be much more beneficial to society.

\section{References}

Banaszak, A. (2018). Welfare as a Form of Ensuring the Social Safety of Society and an Effective and Successful Tool in Election Campaigns (Thoughts Based on the Situation in Contemporary Poland). Regional Formulation and development studies, Vol. 3(26). Klaipeda: Klaipeda University.

Europejska Karta Samorząu Terytorialnego, sporzadzona w Strasburgu dnia 15 października 1985 r. (Dz.U. 1994 nr. 124 poz. 607).

Gruszeczka, M. (2018). Finansowanie wyborów samorządowych. Ile kosztują wybory samorządowe? Gazeta Wyborc$z a$-on-line version, 08.05.2018. Available at: http://wiadomosci.gazeta.pl/wiadomosci/7,114884,23371411,finanso wanie-wyborow-samorzadowych-ile-kosztuja-wybory-samorzadowe.html [Accessed: October 10, 2018].

Izdebski, H., Kulesza, M. (2004). Administracja publiczna. Zagadnienia ogólne. Warszawa: Liber Publishing House.

Jagoda, J. (2011). Sąowa ochrona samodzielności jednostek samorzadu terytorialnego. Warszawa: Wolters Kluwer Publishing House.

Kowalczyk, G. (2018). O co Polska spiera się z Unią Europejską? Konflikt o praworządność to nie wszystko. Dziennik. pl, 30.08.2018 Available at: https://wiadomosci.dziennik.pl/swiat/artykuly/580190, ue-unia-europejska-ke-komisjaeuropejska-polska-pis-rzad-konflikt.html [Accessed: October 10, 2018].

Kulesza, M., Węgrzyn, L. (2006). Vademecum skutecznego działania w samorządzie. Warszawa: Twigger Publishing House.

Kwaśny, J. (2009). Rola samorządu terytorialnego w procesie rozwoju lokalnego gminy na przykładzie miasta Tarnowa. Zeszyty naukowe Małopolskiej Wyższej Szkoty Ekonomicznej w Tarnowie, Vol. 2(13). Tarnów: Publishing House of Małopolska Wyższa Szkoła Ekonomiczna. 
Państwowa Komisja Wyborcza. (2018). Wyjaśnienia Państwowej Komisji Wyborczej z dnia 13 sierpnia 2018 r. dotyczace zasad finansowania kampanii wyborczej w wyborach organów jednostek samorzadu terytorialnego zarządzonych na dzień 21 października 2018 r. Available at: https://pkw.gov.pl/778_Finansowanie_kampanii wyborczej/1/26399_Wyjasnienia_Panstwowej_Komisji_Wyborczej_z_dnia_13_sierpnia_2018_r_dotyczace_zasad_finansowania_kampanii_wyborczej_w_wyborach_organow_jednostek_samorzadu_terytorialnego_zarzadzonych_na_dzien_21_pazdziernika_2018_r[ĀAccessed: November 15, 2018].

Puls Biznesu. (2018). SLD: dwie kadencje dla posłów i likwidacja Senatu. Puls Biznesu: on-line version, 07.04.2018. Available at: https://www.pb.pl/sld-dwie-kadencje-dla-poslow-i-likwidacja-senatu-909870 [Accessed: November 10, 2018].

Rzeczypospolita.pl (2017). Portal o samorządzie lokalnym. Available at: www.rp.pl/samorzad 2018 [Accessed: December 21, 2017].

Zychal, R. (2017). Gerrymandering. Jak politycy decydują za wyborców. Publikacja Onet.pl. Available at: https:// wiadomosci.onet.pl/tylko-w-onecie/czym-jest-gerrymandering/7y2rf6q [Accessed: November 10, 2018].

Robertson, D. (2009). Stownik polityki. Warszawa: Sic Publishing House.

The Constitution of the Republic of Poland (Dz.U., Nr. 78 poz. 483). Text in the English language available at: http:// www.sejm.gov.pl/prawo/konst/angielski/kon1.htm [Accessed: May 20, 2018]. Journal of Laws, No. 78, Item 483.

Ustawa z dn. 28 lipca 1998 r. o wprowadzeniu zasadniczego trójstopniowego podziału terytorialnego państwa (Dz.U z 1998 r., nr. 96, poz. 603).

Ustawa z dn. 5 czerwca 1998 r. o samorzadzie powiatowym (Dz.U. z 1998 r., nr. 91, poz. 578).

Ustawa z dn. 5 czerwca 1998 r. o samorządzie wojewódzkim (Dz.U. z 1998 r., nr. 91, poz. 576).

Ustawa z dn. 8 marca 1990 r. o samorządzie terytorialnym (Dz.U. z 1990 r., nr. 16, poz.94).

Ustawy z dnia 5 stycznia 2011 r. Kodeks wyborczy (Dz. U. z 2018 r. poz. 754, poz. 1000 and poz. 1349).

Wałdoch, M. (2016). Zmiana ordynacji wyborczej jako determinanta życia politycznego społeczności lokalnych w pięciu miastach pomorskich (2006-2014). Studia Gdańskie. Wizje i rzeczywistość. Vol. 13, pp. 243-253. Gdańska: Publishing House of Gdańska Wyższa Szkoła Humanistyczna.

\section{VIET OS VALDŽIOS RINKIMŲ, VYKUSI U LE NKIJOJE 2018 METAIS, VERTINIMAS}

\section{Piotr ZientaRski}

Euroregioninès ekonomikos Alcide De Gasperi Universitetas Józefóve (Lenkija)

\section{Santrauka}

2018 m. rinkimai ị vietos valdžią turẻjo didelę ịtaką dabartinei padéčiai Lenkijoje ir šalies ịvaizdžiui bei poveikiui tarptautinèje politikos arenoje. Šis įvykis buvo svarbus, siekiant sužinoti būsimą politinę padètị Lenkijoje, rinkimų rezultatai - tai galimybė prognozuoti rinkimų rezultatus prieš Europos Parlamento, Lenkijos Seimo ir prezidento rinkimus, kurie vyks ateinančiais metais. Šių rinkimų rezultatai atskleidè ne tik tai, kas gali atsitikti ir kaip Lenkija gali veikti tarptautinejje aplinkoje - bendradarbiavimas kitų šalių regionais ir veikla Europos Sajungoje. Šio tyrimo tikslas - išanalizuoti 2018 m. Lenkijos vietos valdžios rinkimus ir parodyti, kokie pakeitimai atlikti Lenkijos rinkimų įstatyme. Aptarti požymiai, koks artimiausioje ateityje turètų büti vietos valdžios vaidmuo.

Straipsnyje taikomas stebejjimo metodas, politinès situacijos analizè ir Lenkijos galimos politinès ateities prognozavimas, daugiausia dèmesio skiriant tarptautiniam bendradarbiavimui, ypač bendradarbiavimui kaimyninèse šalyse ir Europos Sajungoje. Atskleista, kaip artimiausiu metu skirtingais lygmenimis turètu būti keičiami Lenkijos vietos valdžios vaidmenys ir formos, siekiant pagerinti šių svarbių Lenkijos politinès sistemos ịstaigų veikimą. $2018 \mathrm{~m}$. rinkimai atskleidè ir tai, kad artimiausioje ateityje politinè padètis Lenkijoje gali pasikeisti. Galimi du scenarijai: po būsimų rinkimų Seime, jei vis dar bus dauguma mąstančių taip, 
kaip ir dabartinè dauguma vietos valdžioje, stebėsime politikos radikalëjimą Lenkijoje, nepriimtinus teisès sistemos pokyčius, ekonomikos galios mažejimą ir konfliktus su daugeliu tarptautinių institucijų, taip pat ir Europos Sajungos naremis. Antrasis scenarijus: vieninga opozicija ịgauna galią ir bando inicijuoti visus būtinus pokyčius, siekdama pakeisti padètį Lenkijoje, laikytis teisès normų ir puoselèti demokratiją, tai pagerintų Lenkijos poziciją tarptautinèje arenoje. Opozicinių partijų strategija, taikoma savivaldos rinkimuose, gali būti taikoma ir per rinkimus ị Seimą, taip galima pašalinti dabar vietos valdžioje esančias politines jègas. Pasak daugelio ekspertų, šis scenarijus būtų daug naudingesnis visuomenei.

PAGRINDINIAI ŽODŽIAI: rinkimai 2018 m., bendrija, savivaldybè, Seimas.

JEL KLASIFIKACIJA: K 16, Z 18.

Received: 2018.12 .02

Revised: 2018.12.16

Accepted: 2019.02.02 